This is a self-archived version of an original article. This version may differ from the original in pagination and typographic details.

Author(s): Fadjukoff, Päivi; Feldt, Taru; Kokko, Katja; Pulkkinen, Lea

Title: Identity Status Change Within Personal Style Clusters : A Longitudinal Perspective From Early Adulthood to Midlife

Year: 2019

Version: Accepted version (Final draft)

Copyright: (c) Taylor \& Francis, 2019.

Rights: In Copyright

Rights url: http://rightsstatements.org/page//nC/1.0/?language=en

Please cite the original version:

Fadjukoff, P., Feldt, T., Kokko, K., \& Pulkkinen, L. (2019). Identity Status Change Within Personal Style Clusters : A Longitudinal Perspective From Early Adulthood to Midlife. Identity, 19(1), 1-17. https://doi.org/10.1080/15283488.2019.1566066 
Running head: PERSONAL STYLES AND IDENTITY

Identity status change within personal style clusters: a longitudinal perspective from early adulthood to midlife

\author{
Päivi Fadjukoff \\ Taru Feldt \\ Katja Kokko \\ Lea Pulkkinen \\ University of Jyväskylä
}

\begin{abstract}
Author Note
Correspondence concerning this article should be addressed to Päivi Fadjukoff, University of Jyväskylä, Finland. Contact: paivi.fadjukoff@,jyu.fi
\end{abstract}

Acknowledgement

The authors thank Mr. Joona Muotka for support in the Mplus analyses. 


\begin{abstract}
Differences in identity stability and change from age 36 through 42 to 50 were examined between three male and female personal style clusters extracted at age 27 . We expected, first, the identity statuses to consistently differ between the clusters, and second, those with the least mature identity to move closer to others during midlife. Differences between the personal style clusters were discovered on all identity statuses across ages. Although significant personal styles x age interactions were not detected, some evidence of pace-of-development differences emerged for women: initial differences in identity maturation between the female groups partially leveled off by midlife. In men, early adulthood identity maturation in the conflicted group was however followed by a re-decline in later midlife.
\end{abstract}

Keywords: identity, development, trajectories, personal styles, personality, adulthood, longitudinal, midlife 


\section{Identity status change within personal style clusters: a longitudinal perspective from early adulthood to midlife}

The associations between personality and identity have mainly been studied in adolescent and student populations, often with variable-centered approaches focusing on associations between individual traits and identity processes, as noted by Luyckx, Teppers, Klimstra, and Rassart (2014). For a complementary view, the present study employed the integrative approach and examined the long term role of personal styles in early adulthood for predicting identity stability and change during midlife. Midlife has remained an understudied age period (Fadjukoff \& Kroger, 2016; Lachman, 2015) although it is an important period of life, both in itself as a time when people make their major contributions to society, and as a link between earlier development and later adulthood; it paves the way for how an individual ages (Lachman, Teshale, \& Agrigoroaei, 2015). The main aim of the present study was to examine whether individual differences in identity stability and change in midlife could be explained by differences between individuals in their broader personal styles in early adulthood. The study employed data drawn from the Jyväskylä Longitudinal Study of Personality and Social Development (JYLS; Pulkkinen, 2017).

For decades, the most widely followed operationalization in identity research has been the identity status paradigm by Marcia $(1966,1993,2007)$, also employed in the present study. It has proven useful and productive to researchers of identity development from adolescence through adulthood (Kroger \& McLean, 2011; Syed, 2012), and the statuses are longitudinally confirmed as distinct and relatively stable, over-time identity status trajectories (Meeus, van de Schoot, Keijsers, \& Branje, 2012). Through the years, the identity statuses have also inspired development of newer models and reconceptualizations (for a recent review, see Cieciuch \& Topolewska, 2017) that have primarily been applied to adolescent and emerging adult populations. 
Marcia $(1966,1993,2007)$ defined the dimensions of exploration and commitment essential in the developing identity process, and outlined four qualitatively distinct identity statuses based on positions on these two dimensions. In identity diffusion, an individual neither has firm commitments nor is actively trying to form them, whereas a person in identity moratorium actively explores alternative identities without yet having made commitments. In foreclosure, commitments are made without an exploratory phase, typically by identifying with parents or with significant others. Finally, in identity achievement relatively firm commitments are made through a period of personal exploration without directly relying to parents or other authorities.

Identity formation is a major developmental task in adolescence (Erikson 1950, 1968). Despite systematic identity maturation in adolescence (e.g., Kroger, Martinussen, \& Marcia, 2010; Meeus, 2011), only about half of young people obtain an achieved identity by early adulthood. Identity development continues during adult years, with notable variation across individuals and identity domains (Cramer, 2004; Cramer, 2017; Fadjukoff, Pulkkinen, \& Kokko, 2016; Kroger et al., 2010; Marcia, 2002). The identity achievement status is the most developmentally sophisticated and mature status, and diffusion the least sophisticated (Al-Owidha, Green, \& Kroger, 2009; Berzonsky \& Adams, 1999; Kroger et al., 2010; Marcia 2007, Waterman, 1999).

A progressive developmental trend toward identity achievement has been found most frequent, women typically reaching achievement earlier than men, but individuals may move in and out of identity statuses in different patterns of variability (Kroger et al., 2010). Also in the present JYLS sample, identity diffusion and moratorium have been shown to generally decrease and achievement to increase with age in adulthood, although significant individual differences emerge (Fadjukoff, 2007; Fadjukoff et al., 2016). The great majority of the 
participants had a committed overall identity, either through achievement or foreclosure, from early adulthood to midlife (Fadjukoff et al., 2016).

Marcia (2002) has argued that there is a need for cyclical identity re-formulation through adulthood, and individuals may temporarily regress to earlier identity modes as they encounter identity-disequilibrating circumstances. Referring to this cyclical nature of adult identity re-formulation, and confirming early adulthood reclosure patterns found by Valde (1996), foreclosure-achievement (FAFA) cycles have been detected in the present sample by Pulkkinen and Kokko (2000) foreclosure peaking for many specifically at age 36 (see also Fadjukoff et al., 2016).

Furthermore, an individual's identity development may proceed at a different pace within different domains, depending on the individual's interests and environment (Fadjukoff et al., 2016; Marcia, 1993), even though identity is generally referred to as a single, overall concept. Research suggests that toward middle adulthood there is growth toward identity certainty, self-knowledge, cohesion, and stability of identity commitments (Kroger, 2015), and the domains unite into an integrated sense of identity, highlighting salient domains such as family and work (Fadjukoff, Pulkkinen, \& Kokko, 2005; McLean, Syed, Yoder, \& Greenhoot, 2016; Whitbourne, 1986).

In the integrative perspective of personality by McAdams and Pals (2006), identity and life narratives are defined as a layer of personality, rooted in the more stable personality levels of dispositional traits and characteristic adaptations. The integrated, holistic view to identity and personality has been outlined in early person-centered longitudinal studies. In one of the first such studies on personality development, Block (1971) found five personality types for men and six for women to characterize patterns of personality change from adolescence to adulthood. Whitbourne and Weinstock (1986) reanalyzed Block's findings using the identity status framework, and found that these personality types corresponded to 
Marcia's identity statuses. Generally, adapted personality styles were associated with identity foreclosure, nonconventional styles with identity achievement, and conflicted styles with identity diffusion and moratorium.

In the present study, identity stability and change in middle adulthood was examined in relation to individuals' personal styles in early adulthood. Personal styles were identified by Pulkkinen (1996). She developed a triangular (three-component) model of a personal style to explain it as an organized whole of an individual's personality characteristics, life attitudes, and everyday activities. "A personal[lity] style is a psychological construct consisting of personality characteristics, life orientations, and everyday activities. It represents affective, cognitive, and behavioral components of human action. These components were expected to converge and form different personal[ity] styles" (Pulkkinen, 1996, p. 1288). Pulkkinen (2017) preferred the concept of a personal style to distinguish it more clearly from a personality type based on personality traits, mainly the Big Five traits. In person-centered research, distinguishable and replicable personality types have been extracted for adults using solely dispositional personality traits (e.g., Asendorpf, Borkenau, Ostendorf, \& van Aken, 2001; Kinnunen et al., 2012, see Pulkkinen, 2017).

Pulkkinen used the JYLS age-27-data for the analysis of personal styles. Data were collected by extensive personal interviews which also included structured question series, the Identity Status Interview (Marcia, 1966), a life situation questionnaire, and two standardized personality inventories by Eysenck and Eysenck (1975) and Zuckerman (1979). The interview covered, for instance, marital status, housing, education and work, leisure activities, substance use, life satisfaction, values, personal control, and future orientation. Pulkkinen selected 69 variables to represent personality characteristics (15 variables), everyday activities (34 variables) and life orientation (20 variables). These components approximate, respectively, to dispositional traits, characteristic adaptations, and integrative life narratives 
(McAdams, 2006; McAdams \& Pals, 2006). The four identity status variables were included in the set of life-orientation variables.

Pulkkinen (1996) reduced the number of variables by using a factor analysis for each of the three components and extracted altogether 12 factors: four factors for personality characteristics (extraversion vs. introversion, agreeableness, neuroticism, nonconscientiousness), five factors for behavioral activities (family vs. single life, social integration vs. disintegration, alcoholism, intellectual interests, party culture), and three factors for life orientation (reflectiveness, positive vs. negative life attitudes, resignation vs. exploration). Identity achievement (.68) and diffusion (-.64) were loaded on the factor for reflectiveness with, for instance, motivation to face the future (.58) and internal locus of control (.55). Identity foreclosure (.38) and moratorium (-.68) were loaded on the factor for resignation versus exploration with, for instance, contentment with present achievements without further developmental goals (.58) (Pulkkinen, 1996).

Ward's hierarchical clustering technique was used to empirically extract personal style clusters, separately for men and women. Twelve factor scores for the factors listed above were used as clustering variables (for a detailed description of the method, see Pulkkinen, 1996, 2017). The first two clusters differentiated both male and female participants into the clusters for adaptive and conflicted adjustment. When the third cluster was extracted, the adapted cluster further divided into two clusters. Thus the three main personal styles consisted of two clusters for adaptive and one for conflicted adjustment.

For men, the personal styles for adaptive adjustment corresponded to the personality types most commonly found based on the Big Five personality traits (as summarized, e.g., by Asendorpf et al., 2001; and Scholte et al., 2005; also identified by Luyckx et al., 2014).

The Resilients were characterized by high extraversion, high reflectiveness, good social integration, positive life attitudes, and low neuroticism. These characteristics have been found 
typical of identity achievement (e.g., Cramer, 2000; Clancy \& Dollinger, 1993; Kroger \& Marcia, 2011; Luyckx et al., 2014; Mallory, 1989). The Overcontrolled (alternatively labeled introverted in Pulkkinen, 1996) had high scores in introversion, conscientiousness, and social integration but low reflectiveness scores. These characteristics are typical of identity foreclosure, and generally low levels of identity exploration (e.g., Clancy \& Dollinger, 1993; Cramer, 2000; Mallory, 1989).

The adaptive clusters emerging for women (Pulkkinen, 1996, 2017; Pulkkinen, Feldt \& Kokko, 2005) did not differ by personality but rather by social roles and adaptations corresponding to the personality types found by York and John (1992) for midlife women. The Individuated women were characterized by high intellectual interests, exploration and high reflectiveness, scored low on neuroticism, and were rather single life than family oriented (at age 27). These nonconventional women were "Cognitive Copers" (cf. Block, 1971) and had characteristics typical of identity achievement (e.g., Cramer, 2000; Clancy \& Dollinger, 1993; Helson \& Srivastava, 2001; Kroger \& Marcia, 2011; Mallory, 1989; Pulkkinen, Nurmi \& Kokko, 2002; Whitbourne \& Weinstock, 1986). On the contrary, the Traditionals (alternatively labeled Feminines in Pulkkinen, 1996) were a conventional "Female Prototype" group (cf. Block, 1971) with high family orientation, high conscientiousness and extraversion but low exploration (high resignation) scores including foreclosure identity. Also in other studies, these characteristics are typical of identity foreclosed individuals who have been described to typically conduct conventional, sexappropriate, socially stereotypical behavior, and have conservative values (Mallory, 1989; Kroger \& Marcia, 2011; Whitbourne \& Weinstock, 1986), and score high on measures of authoritarianism (Ryeng, Kroger, \& Martinussen, 2013). Women and men with a foreclosed identity status have been argued to have sex role specific values in which interpersonal 
concern is typical for females and issues of power assertion for males (Cramer, 2000; Mallory, 1989).

In conflicted adjustment, the clusters for both genders were more neurotic, less agreeable, and had more negative life attitudes and lower intellectual interests than the adjusted ones (Pulkkinen, 1996). They were less integrated into society, and used alcohol more heavily than others. However, male problems were generally externalized whereas female maladjustment appeared to be characterized by internalizing problems. The genderspecific labels defined the differences between the male and female conflicted styles: The distinctive characteristics of the Undercontrolled men, in addition to those common to male and female conflicted individuals, were high exploration but low conscientiousness, combined with low family orientation, characteristics that have been found specifically typical of male identity moratorium (e.g. Cramer, 2000; Mallory, 1989). The Brittle women, however, were defined by high introversion and low reflectiveness (including identity diffusion), characteristics typical of identity diffusion also in other studies (e.g., Clancy and Dollinger, 1993; Cramer, 2000; Mallory, 1989).

It can be seen that the four identity statuses were differentially involved in personal styles in terms of the factors for high vs low reflectiveness and exploration vs. resignation. The personal style clusters indicate the context of identity statuses on the edge of adulthood at age 27 . Although identity measures had been included in the original personal style analysis and were loaded on the life-orientation factors, the identity status scores of different personal style groups have not been previously reported.

We expected that the patterns of identity development differ between and within the personal styles also in later adulthood. Firstly, the individuals with personal styles reflecting adaptive adjustment were expected to be consistently characterized by the committed identity statuses: Resilient men and Individuated women by achievement, and Overcontrolled men 
and Traditional women by foreclosure. Individuals with personal styles reflecting conflicted adjustment were expected to score highest in the noncommitted statuses of identity, moratorium and diffusion. The frequency of moratorium identity in midlife was known to be very low (Fadjukoff et al., 2016). Secondly, we expected that the pace of development would vary between the clusters. Personality research suggests that individuals who already at young age have reached mature levels with respect to dispositional traits, change less with age compared to those who have had more room for improvement (McAdams \& Olson, 2010). We expected that a similar trend may emerge in identity development, meaning that the conflicted groups with less mature identity at age 27 would in their development catch up with individuals in the adjusted personal style clusters, and the differences between the clusters would diminish across age.

\section{Method}

\section{Participants}

The study was part of the Jyväskylä Longitudinal Study of Personality and Social Development (JYLS; Pulkkinen, 2017). The original sample of the study consisted of 8-yearolds, 173 girls and 196 boys, born in 1959. The sample comprised 12 randomly drawn complete regular school classes situated in downtown and suburban areas of the city of Jyväskylä, Finland. No initial attrition existed. The sample was ethnically homogeneous; it consisted of Finnish-speaking Finnish citizens, mostly Lutheran by religion. The sample was, at ages 36, 42 and 50, representative of the population of Finnish citizens born in 1959 when compared with data derived from Statistics Finland on, for instance, marriage rate and family type, number of children, and employment status (Pulkkinen, 2017). The participation rate from the eligible sample at ages 27 - 50 varied from 81 to $85 \%$ for men and from 85 to $90 \%$ for women (Pulkkinen, 2017, p. 18). 
The sample of the present study consisted of those JYLS participants, 137 women and 138 men for whom the personal style clusters had been determined at age 27. Statistical methods were utilized to ensure including of all available information on their identity interviews at age 27 for descriptive analyses, and at ages 36 (120 women, 118 men), 42 (105 women, $101 \mathrm{men}$ ), and 50 (100 women, $90 \mathrm{men}$ ) for the hierarchical linear modeling.

\section{Personal style clusters in men and women}

The study exploited the personal style clusters extracted by Pulkkinen (1996) based on age-27 variables including an individual's personality characteristics (15 variables), everyday activities (34) variables) and life orientation (20 variables) as described earlier. Three major gender-specific personal style clusters were compared. For men, these clusters were the Resilients $(55,43 \%$ of the men) and the Overcontrolled (41, 32\%) for adaptive adjustment, and the Undercontrolled $(31,24 \%)$ for conflicted adjustment. For women, the respective clusters were the Traditionals (45, 35\% of the women) and the Individuated (56, 48\%) for adaptive adjustment, and the Brittle $(27,21 \%)$ for conflicted adjustment.

\section{Identity Status Interview Procedure}

The identity interview at ages $27,36,42$, and 50 included five domains: religious beliefs, political ideology, occupational career, intimate relationships, and lifestyle (Fadjukoff et al., 2016). Within the Marcian (1966) semi-structured interview, the participants were asked a series of questions about the process of their identity formation for each domain: for instance, whether they had ever thought about the issue; whether they had had conflicting ideas about the issue; whether they had had influential people around or other sources for opinions; and how they had ended up with their present views. On the basis of the participants' reflections, the presence or absence of a period of identity explorations was assessed, as well as the firmness of personal commitment. The semi-structured nature of the interview allowed for additional questions where necessary, and the whole interview was 
utilized in coding of these dimensions as indicators of discrete identity status categories. The participants' identity status was determined for each domain using the criteria of exploration and commitment. The statuses were first coded by the interviewers and later, on the basis of transcriptions, by a person unaware of the interviewer's coding. After the double coding, the coding differences were analyzed, discussed, and corrected if deemed necessary. The consensus coding was used for data analysis. The rate of full agreement between an interviewer and the second coder varied from 73\% to 93\% (Fadjukoff et al., 2016).

Trained interviewers who had an academic training in psychology conducted the interviews. Interviewers of the later samples were unaware of the previous identity statuses of the interviewees. The assessment was based on the participant's own reflections, and shifting awareness of one's own agency in the commitment process (Pulkkinen \& Kokko, 2000) or re-closure (Valde, 1996) was possible. As noted by Waterman and Archer (1990, 1993), and Whitbourne, Sneed and Skultety (2002), measuring identity in adults differs from corresponding measurements in adolescents. For instance, instead of only examining the present level of exploration, it needs to be considered whether an earlier crisis has meaningfully contributed to present commitments, or whether previous distinctly different life phases represented exploration of alternatives. Although this and other identity measures have been developed for adolescent studies (Fadjukoff \& Kroger, 2016), the interview method, rather than self-report questionnaires, allowed for adjusting the discussion to be appropriate for each age.

For the present study, these original domain-specific discrete identity status variables were merged to create separate indices for each identity status category (Achievement, Moratorium, Foreclosure, and Diffusion) at each measurement point. In a five-domain interview, six-point indices ( 0 to 5 ) were produced on the basis of the number of domains in which the individual was in a particular status. For example, if an individual was located in 
the identity achievement category for two domains, in the foreclosure status for two domains, and in the moratorium status for one domain, that person received a score of 2 for the Identity Achievement index, 2 for the Foreclosure index, 1 for the Moratorium index, and 0 for the Diffusion index. The procedure, used earlier by Pulkkinen and Rönkä (1994), thus gave equal weighting to all five measured domains through the additive approach (Kroger, 2003). The created indices enabled a wide-ranging view to identity, illustrating the relative position of the participants in each specific status.

\section{Data Analysis}

Patterns of bivariate relations among the four identity status variables were analyzed for descriptive purposes using Pearson correlations across all male and female participants, excluding cases pairwise to include the maximum number of participants. T-tests for independent samples were used to find possible gender differences in the level of the variables. Descriptive information of identity measures included in the male and female personal style clusters extracted in a person oriented approach at age 27 by Pulkkinen (1996) was also included in order to provide a baseline for the follow-up of possible differences in the pace of development between the clusters. A one-way between subjects ANOVA was conducted to assess and compare the initial levels of identity maturity between the personal style clusters. Post hoc comparisons were conducted using the Tukey HSD test if the group's variances were equal, and Tamhane's T2 where the variances were non-equal.

The clusters for male and female personal styles were compared with Mplus (version 8; Muthén \& Muthén, 2012) hierarchical linear modeling (HLM) to investigate changes over time. The means were detected with MLR, an Mplus option for full-information maximum likelihood estimation, which enabled consideration of all available data instead of the listwise deletion. Differences in identity statuses were compared in the three gender-specific clusters from age 36 through 42 to 50. This 3 (group) x 3 (age) analysis used the three clusters of 
personal styles as a between-groups variable and age as a repeated measure, enabling the investigation of (a) the mean level changes of the identity status variables from age 36 and 42 to 50, (b) the differences in the mean levels of these variables between clusters, and, (c) the interaction of these effects (i.e., moderating effects; Baron \& Kenny, 1986). Each of the identity status scores was treated separately as the dependent variable. All analyses were carried out for men and women separately due to the gender-specific personal style clusters.

\section{Results}

\section{Descriptive results}

Correlation coefficients., Correlation coefficients (Table 1) between the identity status scores in the whole sample across the ages demonstrated for both genders the most consistent stability correlations for diffusion (ranging from .38 to .55 in men, and from .21 to .50 in women), and achievement (ranging from .22 to .58 in men, and from .20 to .51 in women). In both genders, the most coherent stability was found for identity diffusion between ages 36 and 42, whereas achievement was most stable between ages 42 and 50. Stability was found for moratorium only from age 27 to age 36 in men and from age 27 to age 40 in women, whereas stability in foreclosure emerged from age 36 to 42 and 50, and from age 42 to 50 in men, but only from age 27 to 50 in women. The identity statuses at each age were technically interdependent, as the maximum total score for all indices was five; thus each score on one of the status indices decreased the possibility of scoring high on the other indices. The negative correlations between the indices at each age reflected this interdependency.

Insert Table 1 about here

Comparison of mean differences. Significant gender differences in the average levels of identity status scores were detected at all ages, that is, 27, 36, 42, and 50. Women 
outscored men in identity foreclosure at age 27, and in achievement at ages 42 and 50 , whereas men outscored women in identity diffusion at ages 27 and 50, and in foreclosure at age 42. In moratorium, significant gender differences did not emerge at any age.

Differences between the personal styles at age 27. The baseline means of identity status profiles at age 27 are given in Table 2 . The identity status profiles significantly differed between the clusters at age 27 for both genders. The Resilient men and Individuated women stood out as the most identity-mature groups, while the Overcontrolled men and the Brittle women had the highest diffusion scores. The Undercontrolled men demonstrated the highest moratorium scores, and the Traditional women were characterized by low moratorium and high foreclosure.

Insert Table 2 about here

\section{Identity Status Change within Male Personal Styles from Age 36 to 50}

Interaction effects. In the follow-up from age 36 to 50, no statistically significant interaction effects of male personal style groups (Resilient, Overcontrolled, and Undercontrolled) and age at measurement on identity development were detected. However, age $\mathrm{x}$ group interaction effects emerged as trends for male identity achievement $(p=.052)$ and diffusion ( $p=.067)$. In their rate of achievement, the Undercontrolled group increased sharply from age 36 to 42 but re-decreased by age 50 while achievement did not decline in the Resilient group, and remained stable and low in the Overcontrolled group. For diffusion, the rate remained low and stable in the Resilients, increased steadily in the Overcontrolled but peaked at age 50 in the Undercontrolled group due to a steep increase from age 42 to 50. 
The main effects of age at measurement (age effect) were significant on all identity statuses (Table 3). Significant main effects of personal styles (group effect) emerged for identity achievement and diffusion.

Insert Table 3 about here

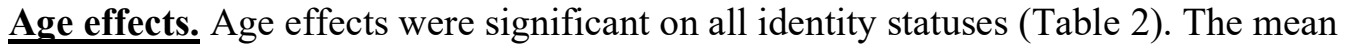
scores of both identity diffusion and achievement increased from age 36 to 42 , and remained stable until age 50. Correspondingly, the mean score of identity foreclosure decreased significantly from age 36 to 42 . The moratorium scores were constantly low but were significantly at their lowest at age 42 . The only significant change in the identity status mean levels after age 42 was an increase in moratorium from age 42 to 50, although the level of moratorium was generally very low in midlife as demonstrated in Figure 1.

Insert Figure 1 about here

Group effects. Personal styles showed significant main effects on identity achievement and diffusion scores (Table 2). In identity achievement, the Resilient men exceeded the Overcontrolled men at all ages and the Undercontrolled men at ages 36 and 50, but also the Undercontrolled men exceeded the Overcontrolled men at age 42. At the opposite pole, the Resilients consistently had the lowest diffusion scores. The Overcontrolled men outscored the Resilient group in identity diffusion at all ages, and the Undercontrolled group at age 42. At age 50, though, the rate of diffusion was highest in the Undercontrolled group. No group differences emerged for identity foreclosure and moratorium scores. 
Interaction effects. No statistically significant interaction effects nor statistical trends of personal styles (Traditional, Individuated, and Brittle) with age at measurement on identity statuses were detected across ages 36,42 , and 50. However, significant age and group effects were also found for women (Table 4).

Insert Table 4 about here

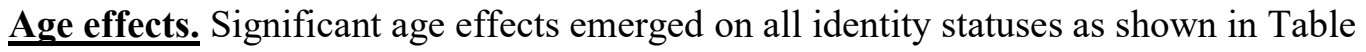
3. Identity achievement and diffusion increased from age 36 to 42 , as in men, but identity diffusion decreased thereafter significantly from age 42 to 50 . As in men, moratorium was at its lowest at age 42 . Thus there were more significant changes in the average level of identity statuses from age 42 to 50 in women than in men in favor of increasing foreclosure and moratorium (Figure 2).

Insert Figure 2 about here

Group effects. Significant differences between the personal style clusters were discovered on all identity statuses. The Individuated women constantly scored the highest in identity achievement, significantly outscoring all other women at ages 36 and 42, and the Brittle women at age 50. As for identity diffusion, the Individuated women scored the lowest and the Brittle the highest, but group differences ceased at age 50. The female groups differed in identity foreclosure only at age 36 when the Traditionals outscored the Individuated women. On the contrary, in moratorium the groups differed only at age 50 when the Individuated women had higher moratorium scores than the Traditionals.

\section{Discussion}


In this person-oriented study, stability and change of identity status differences was studied from age 36 through 42 to 50 years in men and women representing different personal style clusters extracted at age 27 from 12 factor scores as clustering variables, of which identity status variables loaded on two factors.

In line with the integrative framework of personality (McAdams \& Pals, 2006; Pulkkinen, 1992), we first expected the Resilient male and Individuated female styles — representing adaptive adjustment with positive life attitudes and intellectual interests — to be characterized by consistently high identity achievement. This hypothesis was confirmed. Secondly, we expected identity foreclosure to be typical of the Overcontrolled men and the Traditional women. However, no significant differences emerged in foreclosure between the male personal clusters at any measured age. In female clusters, this hypothesis was confirmed only at age 36 . Thirdly, we expected individuals with personal styles reflecting conflicted adjustment (Undercontrolled men and Brittle women) to score highest in the noncommitted statuses of identity moratorium and diffusion. In relation to moratorium, the hypothesis was not confirmed: these conflicted groups did not differ from other clusters even though the Undercontrolled had initially been defined by high moratorium scores at age 27 . The identity status moratorium is rare among adults approaching middle age which explains the lack of differences between personal clusters in moratorium. In relation to diffusion, the hypothesis was partially and gender-specifically confirmed. The Brittle women outscored the other female clusters up to age 42 but the female differences disappeared by age 50 , whereas the difference between the male groups emerged only at age 50 when the Undercontrolled men caught up the Overcontrolled and outscored the Resilient men in diffusion.

We also analyzed whether the pace of development varied between the clusters, specifically whether the groups with less mature identity at age 27 would catch up in their identity development with individuals in the other personal style clusters. Personality traits 
have been found to mature more with age in those who start from lower levels and thus have more room for improvement (McAdams \& Olson, 2010). On the other hand, results show for adults approaching middle age that developmental changes in personality traits depend on the personality profile of an individual (Pulkkinen, 2017, p. 92-95). Rather than becoming more alike, people tend to become more different, because common trends such as the decrease of neuroticism, does not occur among those who are most neurotic, and agreeableness does not increase among those who are least agreeable. Strong evidence of a catching-up pattern in identity development was not found in the present study as indicated by statistically nonsignificant group x age interactions. Low levels of identity maturity (low achievement, high diffusion) were persistent in the Brittle women and Overcontrolled men, although the significance of group differences in female identity diffusion levelled off by age 50 . As a slight indication of such catching-up pattern, the identity achievement and diffusion differences between the Individuated and Traditional female clusters vanished by age 50. In men, the positive trend of speedy achievement increase in the Undercontrolled group up to age 42 first seemed to support this catching-up hypothesis. However, this progressive trend was abruptly replaced by a sudden reverse trend toward higher diffusion by age 50 .

The findings confirm that ego resilience is associated with identity achievement (cf. Cramer, 2000; Grotevant, 1987; Helson \& Srivastava, 2001). The Resilient men seemed to benefit of their positive life attitudes, high reflectiveness and extraversion, and low neuroticism across adulthood in their identity development. This finding is against the early assumption of Whitbourne and Weinstock (1986) that the Resilient have introjected the values of their parents and thus resembled identity foreclosure. Instead, it is in line with more recent findings that achievement is associated with ambitiousness and personally meaningful goals (Helson \& Srivastava, 2001; Pulkkinen, Nurmi, \& Kokko, 2002), high ego resiliency, self-esteem, internal locus of control, and resistance to external pressure (Cramer, 2000; 
Helson \& Srivastava, 2001; Kroger \& Marcia, 2011; Ryeng, Kroger, \& Martinussen, 2013), as well as positive emotionality and emotional adjustment including low levels of neuroticism, depression and anxiety (Cramer, 2000; Clancy \& Dollinger, 1993; Helson \& Srivastava, 2001; Mallory, 1989). Correspondingly, the high intellectual interests, reflectivity, and extensive education of the Individuated women possibly supported their continuously high levels of identity achievement. Success in school, as well as in higher educational levels, has been found to be associated with identity achievement (Fadjukoff \& Pulkkinen, 2006; Fadjukoff, Kokko, \& Pulkkinen, 2007).

Against the hypothesis, identity foreclosure was not consistently related to the personal style clusters in midlife. Specifically the features of the young Traditional women such as conventionality, high family orientation, and low exploration, have been regarded to be typical of identity foreclosed individuals (cf. Mallory, 1989). Yet these characteristics were reflected in identity foreclosure only in young adulthood up to age 36 . Therefore, the high foreclosure scores at age 36 (reported earlier, e.g. by Fadjukoff et al., 2016) were not associated with personal styles but possibly rather related to individual life circumstances or age-graded changes.

The results highlighted the consistent identity challenges of the Overcontrolled male cluster, defined adaptive and well socially integrated at age 27 . It seems that their high introversion and low reflectiveness, features also typical of the female conflicted group Brittles, were detrimental to optimal identity development. The findings associated the group with the "Vulnerable Overcontrollers" by Block (1971). This male group was associated with identity diffusion with crisis by Whitbourne and Weinstock (1986). In line with this, Luyckx and colleagues (2014) found in their follow-up the Overcontrolled adolescents to demonstrate regressive identity profiles, characterized by rumination and low identification with identity commitments. 
The most ambiguous identity patterns emerged in the conflicted male group Undercontrolled, characterized at age 27 by externalizing problems, high exploration and low conscientiousness. Their contradictorily fluctuating rates of identity achievement and diffusion highlighted potential identity challenges in this group, and call for additional research. Fadjukoff et al. (2010) demonstrated in an earlier study that occupational identity fluctuated according to macro-economic circumstances: it progressed to its highest level during economic boom (at age 42 of the participants), and later turned to regression during recession at age 50, accompanied with a weakened sense of agency specifically in men. Occupational identity has been shown to be a good index domain for the overall identity (see, e.g., Kroger et al., 2010; Fadjukoff et al., 2016). The present finding implicates that instead of showing age-related developmental trends, the Undercontrolled men may be specifically vulnerable to such environmental changes and consequent changes in the unemployment rate (cf. Fig.1); their identity achievement peaked up at the time of economic boom (at age 42, in 2001), whereas diffusion peaked up during economic recession (at age 50, in 2009; there was economic recession in Finland also in mid-1990s, cf. Fadjukoff, Kokko, \& Pulkkinen, 2010). The present research was the first attempt to empirically investigate the role of personal styles in post-adolescence identity development. The versatility of the instruments and variables used in defining the personal styles, and the long time span analyzed were advantages of the study. The time span of the analyses was exceptionally long, 23 years, extending from early to middle adulthood. However, we were able only to give an overview of the identity formation trends respective of the personal styles, as the long periods between the measurement points did not enable detecting of continuous processes and movements of identity over time (Kroger, 2015). Neither were we able to consider the contents of identity, but rather the scope of the statuses, and the relative position of the personality style groups in each specific status. With the present sample size and one age cohort, some indicative 
findings did not reach statistical significance, and the age-graded and history-graded influences (Baltes, Lindenberger, \& Staudinger, 1998) could not be differentiated.

Furthermore, male and female developments could be more similar in the Nordic culture than in cultures in which the gender roles are more distinct. Hence, future research is needed to elaborate and to substantiate the generalizability of the results and the inferences reported.

\section{References}

Al-Owidha, A., Green, K. E., \& Kroger, J. (2009). On the question of an identity status category order: Rasch model step and scale statistics used to identify category order. International Journal of Behavioral Development, 33(1), 88-96. doi:10.1177/0165025408100110

Asendorpf, J. B., Borkenau, P., Ostendorf, F., \& van Aken, M. A. G. (2001). Carving personality description at its joints: Confirmation of three replicable personality prototypes for both children and adults. European Journal of Personality, 15, 169198. doi: 10.1002/per.408

Baltes, p. B., Lindenberger, U. \& Staudinger, U. M. (1998). Life-span theory in developmental psychology. In W. Damon \& R. M. Lerner (Eds.) Handbook of child psychology. Vol 1: Theoretical models of Human development. (5 $5^{\text {th }}$ ed.). (pp. 10291117). New York: John Wiley \& Sons.

Baron, R., \& Kenny, D. (1986). The moderator-mediator variable distinction in social psychological research: Conceptual, strategic, and statistical considerations. Journal of Personality and Social Psychology, 51 (6), 1173-1182.

Berzonsky, M. D., \& Adams, G. R. (1999). Re-evaluating the identity status paradigm: Still useful after 35 years [Commentary]. Developmental Review, 19, 557-590. doi: 10.1006/drev.1999.0495 
Block, J. (1971). Lives through time. Berkeley, CA: Bancroft.

Cieciuch, J., \& Topolewska, E. (2017). Circumplex of identity formation modes: A proposal for the integration of identity constructs developed in the Erikson-Marcia tradition. Self and Identity, 16(1), 37-61. doi:10.1080/15298868.2016.1216008

Clancy, S. M., \& Dollinger, S. J. (1993). Identity, self and personality. I. Identity status and the Five-Factor Model of personality. Journal of Research in Adolescence, 3(3), 227245.

Cramer, P. (2000). Development of identity: Gender makes a difference. Journal of Research in Personality, 34(1), 42-72. doi:10.1006/jrpe.1999.2270

Cramer, P. (2004). Identity change in adulthood: The contribution of defense mechanisms and life experiences. Journal of Research in Personality, 38(3), 280-316. doi:10.1016/S0092-6566(03)00070-9

Cramer, P. (2017). Identity change between late adolescence and adulthood. Personality and Individual Differences, 104, 538-543. doi:10.1016/j.paid.2016.08.044

Erikson, E. H. (1950). Childhood and society. New York: Norton.

Erikson, E. H. (1968). Identity, youth and crisis. New York: Norton.

Fadjukoff, P. (2007). Identity formation in adulthood. (Doctoral dissertation) University of Jyväskylä. doi: https://jyx.jyu.fi/dspace/handle/123456789/13394

Fadjukoff, P., Kokko, K., \& Pulkkinen, L. (2007). Implications of timing of entering adulthood for identity achievement. Journal of Adolescent Research, 22(5), 504-530. doi: $10.1177 / 0743558407305420$

Fadjukoff, P., Kokko, K., \& Pulkkinen, L. (2010). Changing Economic Conditions and Identity Formation in Adulthood. European Psychologist, 15(4), 293-303. doi:10.1027/1016-9040/a000061 
Fadjukoff, P., \& Kroger, J. (2016). Identity development in adulthood: Introduction. Identity, 16(1), 1-7. doi:10.1080/15283488.2015.1121821

Fadjukoff, P., \& Pulkkinen, L. (2006). Identity formation, personal control over development, and well-being. In L. Pulkkinen, J. Kaprio, \& R. Rose (Eds.), Socioemotional development and health from adolescence to adulthood. (pp. 265-285). Cambridge: Cambridge University Press. doi: 10.1017/CBO9780511499784.019

Fadjukoff, P., Pulkkinen, L., \& Kokko, K. (2016). Identity formation in adulthood: A longitudinal study from age 27 to 50. Identity, 16(1), 8-23. doi:10.1080/15283488.2015.1121820

Fadjukoff, P., Pulkkinen, L., \& Kokko, K. (2005). Identity processes in adulthood: Diverging domains. Identity, 5(1), 1-20. doi:10.1207/s1532706xid0501_1

Helson, R., \& Srivastava, S. (2001). Three paths of adult development. Journal of Personality and Social Psychology, 80(6), 995-1010. doi:10.1037/0022-3514.80.6.995

Kinnunen, M.-L., Metsäpelto, R. L., Feldt, T., Kokko, K., Tolvanen, A., Kinnunen, U., Leppänen, E. \& Pulkkinen, L. (2012). Personality profiles and health: Longitudinal evidence among Finnish adults. Scandinavian Journal of Psychology 53, 512-522. doi: $10.1111 / \mathrm{j} .1467-9450.2012 .00969 . x$

Kroger, J. (2003). What transits in an identity status transition? Identity, 3(3), 197-220. doi: 10.1207/S1532706XID0303_02

Kroger, J. (2015). Identity development through adulthood. In McLean, Kate C. \& Syed, Moin (Eds.), The Oxford handbook of identity development (pp. 65-80). Oxford University Press. doi:10.1093/oxfordhb/9780199936564.013.004

Kroger J., Marcia J.E. (2011). The identity statuses: Origins, meanings, and interpretations. In: Schwartz S., Luyckx K., Vignoles V. (Eds) Handbook of Identity 
Theory and Research. Springer, New York, NY. doi: https://doi.org/10.1007/978-14419-7988-9_2

Kroger, J., Martinussen, M., \& Marcia, J. E. (2010). Identity status change during adolescence and young adulthood: A meta-analysis. Journal of Adolescence, 33(5), 683698. doi: https://doi.org/10.1016/j.adolescence.2009.11.002

Kroger, J., \& McLean, K. C. (2011). Identity narratives during the adult years. In C. Hoare (Ed.), The Oxford handbook of reciprocal adult development and learning (2nd ed., pp. 173-185). New York, NY: Oxford University Press. doi:10.1093/oxfordhb/9780199736300.013.0060

Lachman, M. E. (2015). Mind the gap in the middle: A call to study midlife. Research in Human Development, 12(3-4), 327-334. doi:10.1080/15427609.2015.1068048

Lachman, M. E., Teshale, S., \& Agrigoroaei, S. (2015). Midlife as a pivotal period in the life course. International Journal of Behavioral Development, 39(1), 20-31. doi:10.1177/0165025414533223

Luyckx, K., Teppers, E., Klimstra, T. A., \& Rassart, J. (2014). Identity processes and personality traits and types in adolescence: Directionality of effects and developmental trajectories. Developmental Psychology, 50(8), 2144-2153. doi:10.1037/a0037256

Mallory, M. E. (1989). Q-sort definition of ego identity status. Journal of Youth and Adolescence, 18(4), 399-412. doi:10.1007/BF02139257

Marcia, J. E. (1966). Development and validation of ego-identity status. Journal of Personality and Social Psychology, 3, 551-558. doi: 10.1037/h0023281

Marcia, J. E. (1993). The ego identity status approach to ego identity. In J.E. Marcia, A.S. Waterman, D. R. Matteson, S. L. Archer, \& J. L. Orlofsky (Eds.), Ego identity: A handbook for psychosocial research (pp. 3-21). New York: Springer-Verlag. doi: https://link.springer.com/chapter/10.1007/978-1-4613-8330-7_1 
Marcia, J. E. (2002). Identity and psychosocial development in adulthood. Identity, 2(1), $7-$ 28. doi: 10.1207/S1532706XID0201_02

Marcia, J. E. (2007). Theory and measure: The identity status interview. In M. Watzlawik, \& A. Born (Eds.), Capturing identity: Quantitative and qualitative methods (pp. 1-14). Lanham, MD: University Press of America.

McAdams, D. P. (2006). The role of narrative in personality psychology today. Narrative Inquiry, 16, 11-18. doi:10.1075/ni.16.1.04mca

McAdams, D. P., \& Olson, B. D. (2010). Personality development: Continuity and change over the life course. Annual Review of Psychology, 61(1), 517-542. doi:10.1146/annurev.psych.093008.100507

McAdams, D. P. \& Pals, J. L. (2006). A new big five. Fundamental principles for an integrative science of personality. American Psychologist, 61, 204-217. doi:10.1037/0003-066X.61.3.204

McLean, K. C., Syed, M., Yoder, A., \& Greenhoot, A. F. (2016). The role of domain content in understanding identity development processes. Journal of Research on Adolescence, 26(1), 60-75. doi:10.1111/jora.12169

Meeus, W. (2011). The study of adolescent identity formation 2000-2010: A review of longitudinal research. Journal of Research on Adolescence, 21(1), 75-94. doi:10.1111/j.1532-7795.2010.00716.x

Meeus, W., van de Schoot, R., Keijsers, L., \& Branje, S. (2012). Identity statuses as developmental trajectories: A five-wave longitudinal study in early-to-middle and middle-to-late adolescents. Journal of Youth and Adolescence, 41(8), 1008-1021. doi:10.1007/s10964-011-9730-y

Muthén, L. K., \& Muthén, B. O. (2012). Mplus Version 7 user's guide. Los Angeles, CA: Muthén \& Muthén.Osgood, D. W., Ruth, G., Eccles, J. S., Jacobs, J. E., \& Barber, B. L. 
(2005). Six paths to adulthood; Fast starters, parents without careers, educated partners, educated singles, working singles, and slow starters. In R. A. Settersten, Jr., F. F. Furstenberg, \& R. C. Rumbaut (Eds.) On the frontier of adulthood: Theory, research, and public policy (pp 320-355). Chicago: University of Chicago Press.

Pulkkinen, L. (1992). Life-styles in personality development. European Journal of Personality, 6(2), 139-155. doi: 10.1002/per.2410060206

Pulkkinen, L. (1996). Female and male personality styles: A typological and developmental analysis. Journal of Personality and Social Psychology, 70(6), 1288-1306. doi: http://dx.doi.org/10.1037/0022-3514.70.6.1288

Pulkkinen, L. (2017). Human development from middle childhood to middle adulthood. (In collaboration with Katja Kokko.) London: Routledge.

Pulkkinen, L., Feldt, T., \& Kokko, K. (2005). Personality in young adulthood and functioning in middle age. In S. Willis \& M. Martin (Eds.). Middle adulthood: A lifespan perspective (pp. 99-141). Thousand Oaks, CA: Sage.

Pulkkinen, L., \& Kokko, K. (2000). Identity development in adulthood: A longitudinal study. Journal of Research in Personality, 34, 445-470. doi:10.1006/jrpe.2000.2296

Pulkkinen, L., Nurmi, J.-E., \& Kokko, K. (2002). Individual differences in personality goals in mid-thirties. In L. Pulkkinen \& A. Caspi (Eds.), Paths to successful development: Personality in the life course. (pp. 331-352). Cambridge, UK: Cambridge University Press.

Pulkkinen, L. \& Rönkä, A. (1994). Personal control over development, identity formation, and future orientation as components of life orientation: A developmental approach. Developmental Psychology, 30(2), 260-271. doi: http://dx.doi.org/10.1037/00121649.30.2.260 
Ryeng, M. S., Kroger, J., \& Martinussen, M. (2013). Identity status and authoritarianism: A meta-analysis. Identity, 13(3), 242-252. doi:10.1080/15283488.2013.799434

Scholte, R., van Lieshout, C. F. M., de Wit, C. A. M., van Aken, M. A. G. (2005). Adolescent personality types and subtypes and their psychosocial adjustment. Merrill-Palmer Quarterly, 51(3), 258-286.

Syed, M. (2012). The past, present, and future of eriksonian identity research: Introduction to the special issue. Identity, 12(1), 1-7. doi:10.1080/15283488.2012.632362

Valde, G. A. (1996). Identity closure: A fifth identity status. The Journal of Genetic Psychology, 157(3), 245-254. doi: 10.1080/00221325.1996.9914862

Waterman, A. S. (1999). Commentary. Identity, the identity statuses, and identity status development: A contemporary statement. Developmental Review, 19, 591-621. doi:10.1006/drev.1999.0493

Waterman, A. S. \& Archer, S. (1990). A lifespan perspective on identity formation: developments in form, function, and process. In Baltes, P. B., Featherman, D. L., \& Lerner, R. M. (Eds.) Life-span Development \& Behavior. Vol 10, pp. 29-37. Orlando, FL: Academic Press.

Waterman, A. S., \& Archer, S. (1993). Identity status during the adult years: Scoring criteria. In J. E. Marcia, A. S. Waterman, D. R. Matteson, S. L. Archer, \& J. L. Orlofsky (Eds.), Ego identity: A handbook for psychosocial research (pp. 241-333). New York: Springer. doi: 10.1007/978-1-4613-8330-7_10

Whitbourne, S. K. (1986). The me I know: A study of adult identity. New York: Springer. Whitbourne, S. K., Sneed, J. R. \& Skultety, K. M. (2002). Identity processes in adulthood: theoretical and methodological challenges. Identity: An International Journal of Theory and Research, 2, 29-45. 
Whitbourne, S. K., \& Weinstock, C. S. (1986). Adult development. (2 ${ }^{\text {nd }}$ ed.). New York: Praeger.

York, K. L., \& John, O. P. (1992). The four faces of Eve: A typological analysis of women's personality at midlife. Journal of Personality and Social Psychology, 63(3), 494-508. 
Table 1.

Pairwise Pearson correlations between the Identity Status Scores, separately for men (below the diagonal), and women (above the diagonal).

The test correlations across age levels are bolded.

\begin{tabular}{|c|c|c|c|c|c|c|c|c|c|c|c|c|c|c|c|c|c|c|c|c|}
\hline \multirow{2}{*}{$\begin{array}{l}\text { Identity Status } \\
\text { Scores }\end{array}$} & \multirow{2}{*}{$\begin{array}{c}\text { Men } \\
M(S D)\end{array}$} & \multirow{2}{*}{$\begin{array}{l}\text { Women } \\
M(S D)\end{array}$} & \multicolumn{2}{|c|}{ Gender difference } & \multicolumn{4}{|c|}{ Age 27} & \multicolumn{4}{|c|}{ Age 36} & \multicolumn{4}{|c|}{ Age 42} & \multicolumn{4}{|c|}{ Age 50} \\
\hline & & & $t$ & $p$ & 1 & 2 & 3 & 4 & 5 & 6 & 7 & 8 & 9 & 10 & 11 & 12 & 13 & 14 & 15 & 16 \\
\hline Identity at age 27 & $N=137$ & $N=137$ & $(d f=272)$ & & & & & & & & & & & & & & & & & \\
\hline 1 Achievement & $1.28(1.30)$ & $1.41(1.29)$ & 0.79 & .428 & - & $-.19^{*}$ & $-.40^{* * *}$ & $-.51^{* * *}$ & $.28^{* *}$ & -.06 & -.11 & $-.22^{*}$ & $.31^{* * * *}$ & -.08 & -.15 & $-.24^{*}$ & $.20^{*}$ & .04 & -.16 & -.05 \\
\hline 2 Moratorium & $0.98(1.11)$ & $0.91(0.98)$ & -0.58 & .566 & $-.23^{* *}$ & - & $-.36^{* * *}$ & $-.26^{* * *}$ & $.18^{*}$ & .13 & $-.22^{*}$ & -.07 & .13 & $.36^{* * *}$ & -.11 & -.16 & .13 & .02 & -.07 & -.07 \\
\hline 3 Foreclosure & $1.01(0.95)$ & $1.42(1.19)$ & $3.09 \mathrm{a}$ & .002 & $-.23^{* *}$ & $-.35^{* * *}$ & - & $-.27^{* *}$ & -.11 & -.11 & .13 & .07 & -.10 & -.13 & .15 & .01 & -.12 & -.16 & $.29^{* *}$ & -.11 \\
\hline 4 Diffusion & $1.72(1.37)$ & $1.27(1.28)$ & -2.84 & .005 & $-.60^{* * *}$ & $-.35^{* * *}$ & $-.20^{*}$ & - & $-.33^{* * *}$ & .06 & .17 & $.21^{*}$ & $-.34^{* * *}$ & -.08 & .09 & $.38^{* * *}$ & -.20 & .10 & -.04 & $.22^{*}$ \\
\hline Identity at age 36 & $N=118$ & $N=120$ & $(d f=236)$ & & & & & & & & & & & & & & & & & \\
\hline 5 Achievement & $1.48(1.45)$ & $1.71(1.33)$ & 1.25 & .214 & $.28^{* * *}$ & $.16^{*}$ & .05 & $-.44^{* * *}$ & - & $-.18^{*}$ & $-.62^{* * *}$ & $-.51^{* * *}$ & $.39^{* * * *}$ & .12 & -.15 & $-.44^{* * *}$ & $.48^{* * *}$ & .09 & $-.41^{* * *}$ & -.19 \\
\hline 6 Moratorium & $0.21(0.54)$ & $0.34(0.69)$ & $1.62_{\mathrm{a}}$ & .107 & -.06 & $.19^{*}$ & -.07 & -.05 & -.14 & - & $-.30^{* * *}$ & -.09 & .07 & .03 & $-.20^{*}$ & .13 & -.17 & .07 & .11 & .12 \\
\hline 7 Foreclosure & $2.25(1.20)$ & $2.07(1.19)$ & -1.20 & .248 & -.08 & -.08 & .04 & .11 & $-.57^{* * *}$ & $-.26^{* *}$ & - & $-.17^{*}$ & -.19 & -.07 & $.23^{*}$ & -.03 & $-.21^{*}$ & -.04 & $.22^{*}$ & .06 \\
\hline 8 Diffusion & $1.03(1.12)$ & $0.88(0.94)$ & $-1.12_{\mathrm{a}}$ & .263 & $-.26^{* *}$ & $-.22^{*}$ & -.05 & $.48^{* * *}$ & $-.60^{* * *}$ & -.01 & $-.20^{*}$ & - & $-.37^{* * *}$ & -.10 & .07 & $.50^{* * *}$ & $-.30^{* *}$ & -.15 & $.22^{*}$ & $.29^{* * *}$ \\
\hline Identity at age 42 & $N=101$ & $N=105$ & $(d f=204)$ & & & & & & & & & & & & & & & & & \\
\hline 9 Achievement & $1.92(1.52)$ & $2.43(1.44)$ & 2.46 & .015 & $.22^{*}$ & .12 & .08 & $-.40^{* * *}$ & $.45^{* * *}$ & .08 & $-.26^{*}$ & $-.37^{* * *}$ & - & .00 & $-.69^{* * *}$ & $-.62^{* * *}$ & $.51^{* * *}$ & .03 & $-.36^{* * *}$ & $-.36^{* * *}$ \\
\hline 10 Moratorium & $0.08(0.27)$ & $0.09(0.28)$ & 0.17 & .866 & .02 & .09 & -.09 & -.03 & $-.22^{*}$ & .18 & $.26^{*}$ & -.05 & -.08 & - & -.06 & $-.21^{*}$ & .14 & .12 & -.12 & -.16 \\
\hline 11 Foreclosure & $1.74(1.26)$ & $1.32(1.12)$ & -2.52 & .013 & -.09 & -.05 & .10 & .07 & -.05 & $-.29^{* *}$ & $.25^{*}$ & -.06 & $-.66^{* * *}$ & -.06 & - & -.10 & $-.23^{*}$ & -.15 & $.26^{*}$ & .11 \\
\hline 12 Diffusion & $1.26(1.16)$ & $1.16(1.07)$ & -0.61 & .539 & $-.22^{*}$ & -.17 & -.12 & $.46^{* * *}$ & $-.46^{* * *}$ & .15 & .01 & $.55^{* * *}$ & $-.58^{* * *}$ & -.06 & $-.21^{*}$ & - & $-.48^{* * *}$ & .09 & $.24^{*}$ & $.42^{* * * *}$ \\
\hline Identity at age 50 & $N=90$ & $N=100$ & $(d f=188)$ & & & & & & & & & & & & & & & & & \\
\hline 13 Achievement & $1.92(1.55)$ & $2.25(1.47)$ & 1.49 & .137 & $.35^{* * *}$ & .15 & .05 & $-.50^{* * *}$ & $.47^{* * *}$ & -.07 & -.14 & $-.47^{* * *}$ & $.58^{* * * *}$ & -.14 & -.25 & $-.49^{* * *}$ & - & -.11 & $-.73^{* * *}$ & $-.47^{* * *}$ \\
\hline 14 Moratorium & $0.26(0.46)$ & $0.32(0.57)$ & 0.85 & .395 & .12 & .04 & -.19 & -.01 & -.06 & .05 & .00 & .05 & .01 & .22 & -.02 & .05 & -.21 & - & $-.23^{*}$ & -.09 \\
\hline 15 Foreclosure & $1.36(1.12)$ & $1.65(1.30)$ & $1.67 \mathrm{a}$ & .094 & -.06 & $-.23^{*}$ & .07 & .21 & $-.33^{* *}$ & -.10 & $.28^{*}$ & .18 & $-.39^{* * *}$ & .20 & $.31^{* * *}$ & .16 & $-.43^{* * *}$ & $-.24^{*}$ & - & -.03 \\
\hline 16 Diffusion & $1.47(1.35)$ & $0.73(0.83)$ & $-4.58 \mathrm{a}$ & .000 & $-.40^{* * *}$ & .01 & -.05 & $.41^{* * * *}$ & $-.25^{*}$ & .15 & -.08 & $.38^{* * *}$ & $-.36^{* * *}$ & -.09 & .03 & $.47^{* * * *}$ & $-.72^{* * *}$ & .10 & $-.25^{*}$ & - \\
\hline
\end{tabular}

Note: $* * * p<.001 ; * * p<.01 ; * p<.05$

Note: ${ }_{a}$ Equal variances not assumed in the following $t$-tests: variable $3 d f=258.8$; variable $6 d f=223.9$; variable $8 d f=227.1$; variable $15 d f=187.6$; variable 16 $d f=144.4$ 
Table 2.

Baseline information of identity

\begin{tabular}{|c|c|c|c|c|c|c|c|c|c|}
\hline $\begin{array}{l}\text { Male Personal } \\
\text { Styles }\end{array}$ & \multicolumn{2}{|c|}{$\begin{array}{l}\text { Resilient } \\
(N=58)\end{array}$} & \multicolumn{2}{|c|}{$\begin{array}{l}\text { Overcontrolle } \\
\mathrm{d}(\mathrm{N}=44)\end{array}$} & \multicolumn{2}{|c|}{$\begin{array}{l}\text { Undercontrolle } \\
\mathrm{d}(\mathrm{N}=35)\end{array}$} & \multirow[b]{2}{*}{$F$} & \multirow[b]{2}{*}{$p$} & \multirow{2}{*}{$\begin{array}{l}\text { Group } \\
\text { diff. }\end{array}$} \\
\hline$N=137$ & $M$ & $S D$ & $M$ & $S D$ & $M$ & $S D$ & & & \\
\hline Achievement & 1.91 & 1.30 & .82 & 1.15 & .83 & 1.04 & 14.03 & $<.001$ & $\mathrm{R}>\mathrm{O}, \mathrm{U}$ \\
\hline Foreclosure & 1.14 & .93 & .86 & .88 & 1.00 & 1.06 & 1.06 & .351 & \\
\hline Moratorium & .78 & .99 & .89 & .97 & 1.43 & 1.36 & 4.15 & .018 & $\mathrm{U}>\mathrm{R}$ \\
\hline Diffusion & 1.16 & 1.09 & 2.43 & 1,40 & 1.74 & 1.34 & 12.83 & $<.001$ & $\mathrm{O}>\mathrm{R}, \mathrm{U}$ \\
\hline $\begin{array}{l}\text { Female Personal } \\
\text { Styles }\end{array}$ & \multicolumn{2}{|c|}{$\begin{array}{l}\text { Individuated } \\
\qquad(N=59)\end{array}$} & \multicolumn{2}{|c|}{$\begin{array}{l}\text { Traditional } \\
(N=48)\end{array}$} & \multicolumn{2}{|c|}{$\begin{array}{l}\text { Brittle } \\
(N=30)\end{array}$} & & & Groun \\
\hline$N=137$ & $M$ & $S D$ & $M$ & $S D$ & $M$ & $S D$ & $F$ & $p$ & diff. \\
\hline Achievement & 1.75 & 1.38 & 1.33 & .95 & .87 & .97 & 5.05 & .008 & $\mathrm{I}>\mathrm{B}$ \\
\hline Foreclosure & 1.02 & 1.01 & 1.96 & 1.05 & 1.33 & 1.42 & 9.37 & $<.001$ & $\mathrm{~T}>\mathrm{I}$ \\
\hline Moratorium & 1.19 & .95 & .42 & .65 & 1.13 & 1.20 & 10.39 & $<.001$ & $\mathrm{I}, \mathrm{B}>\mathrm{T}$ \\
\hline Diffusion & 1.05 & 1.18 & 1.29 & 1.17 & 1.67 & 1.35 & 2.57 & .080 & \\
\hline
\end{tabular}


Table 3.

Identity statuses in three male groups of personal styles at ages 36, 42, and 50. A comparison conducted by MPlus hierarchical linear modeling with full-information maximum likelihood estimation.

\begin{tabular}{|c|c|c|c|c|c|c|c|c|c|c|c|c|}
\hline \multirow[b]{2}{*}{ Identity status } & \multicolumn{3}{|c|}{ 1. Resilients } & \multicolumn{3}{|c|}{$\begin{array}{c}\text { 2. Over- } \\
\text { controlled }\end{array}$} & \multicolumn{3}{|c|}{$\begin{array}{l}\text { 3. Under- } \\
\text { controlled }\end{array}$} & \multirow[b]{2}{*}{$\begin{array}{l}\text { Age x } \\
\text { Group }^{(a}\end{array}$} & \multirow[b]{2}{*}{$\begin{array}{l}\text { Age } \\
\text { effect }^{(\mathrm{a}} \\
(\mathrm{F})\end{array}$} & \multirow[b]{2}{*}{$\begin{array}{c}\text { Group } \\
\text { effect }^{(\mathrm{a}} \\
(\mathrm{F})\end{array}$} \\
\hline & $\begin{array}{c}M \\
\text { (S.E.) } \\
\text { Age } \\
36\end{array}$ & $\begin{array}{c}M \\
\text { (S.E.) } \\
\text { Age } \\
42\end{array}$ & $\begin{array}{c}M \\
\text { (S.E.) } \\
\text { Age } \\
50\end{array}$ & $\begin{array}{c}M \\
\text { (S.E.) } \\
\text { Age } \\
36\end{array}$ & $\begin{array}{c}M \\
\text { (S.E.) } \\
\text { Age } \\
42\end{array}$ & $\begin{array}{c}M \\
\text { (S.E.) } \\
\text { Age } \\
50\end{array}$ & $\begin{array}{c}M \\
\text { (S.E.) } \\
\text { Age } \\
36\end{array}$ & $\begin{array}{c}M \\
\text { (S.E.) } \\
\text { Age } \\
42\end{array}$ & $\begin{array}{c}M \\
\text { (S.E.) } \\
\text { Age } \\
50\end{array}$ & & & \\
\hline Achievement & $\begin{array}{c}1.83 \\
(0.22)\end{array}$ & $\begin{array}{c}2.40 \\
(0.20)\end{array}$ & $\begin{array}{c}2.56 \\
(0.23)\end{array}$ & $\begin{array}{c}1.20 \\
(0.21)\end{array}$ & $\begin{array}{c}1.01 \\
(0.23)\end{array}$ & $\begin{array}{c}1.32 \\
(0.23)\end{array}$ & $\begin{array}{c}1.20 \\
(0.24)\end{array}$ & $\begin{array}{c}1.99 \\
(0.30)\end{array}$ & $\begin{array}{l}1.45 \\
(0.30)\end{array}$ & $3.55 n s$ & $\begin{array}{l}8.89 * \\
36<42\end{array}$ & $\begin{array}{l}\text { At } 36: 5.54 \dagger \\
1>2,3 \\
\text { At } 42: 21.68^{* * *} \\
1>2 ; 3>2 \\
\text { At } 50: 16.69^{* * *} \\
1>2,3\end{array}$ \\
\hline Moratorium & $\begin{array}{c}0.15 \\
(0.07)\end{array}$ & $\begin{array}{c}0.08 \\
(0.04)\end{array}$ & $\begin{array}{c}0.26 \\
(0.08)\end{array}$ & $\begin{array}{c}0.18 \\
(0.09)\end{array}$ & $\begin{array}{c}0.03 \\
(0.03)\end{array}$ & $\begin{array}{c}0.21 \\
(0.08)\end{array}$ & $\begin{array}{c}0.37 \\
(0.11)\end{array}$ & $\begin{array}{c}0.12 \\
(0.07)\end{array}$ & $\begin{array}{c}0.35 \\
(0.11)\end{array}$ & $3.12 n s$. & $\begin{array}{l}16.24 * * * \\
36>42<50\end{array}$ & $\begin{array}{l}\text { At 36: } 3.11 n s \\
\text { At 42: } 2.05 n s \\
\text { At 50: } 1.04 n s\end{array}$ \\
\hline Foreclosure & $\begin{array}{c}2.22 \\
(0.18)\end{array}$ & $\begin{array}{c}1.53 \\
(0.18)\end{array}$ & $\begin{array}{c}1.31 \\
(0.16)\end{array}$ & $\begin{array}{c}2.33 \\
(0.17)\end{array}$ & $\begin{array}{c}2.02 \\
(0.22)\end{array}$ & $\begin{array}{l}1.54 \\
(0.22)\end{array}$ & $\begin{array}{l}2.07 \\
(0.24)\end{array}$ & $\begin{array}{c}1.59 \\
(0.26)\end{array}$ & $\begin{array}{c}1.18 \\
(0.23)\end{array}$ & $0.58 n s$ & $\begin{array}{l}45.52 * * * \\
36>42\end{array}$ & $\begin{array}{l}\text { At 36: } 0.74 n s \\
\text { At 42: } 3.11 n s . \\
\text { At 50: } 1.41 n s .\end{array}$ \\
\hline Diffusion & $\begin{array}{c}0.77 \\
(0.15)\end{array}$ & $\begin{array}{c}1.00 \\
(0.14)\end{array}$ & $\begin{array}{c}0.89 \\
(0.18)\end{array}$ & $\begin{array}{c}1.34 \\
(0.17)\end{array}$ & $\begin{array}{c}1.91 \\
(0.24)\end{array}$ & $\begin{array}{c}1.93 \\
(0.24)\end{array}$ & $\begin{array}{c}1.27 \\
(0.23)\end{array}$ & $\begin{array}{c}1.22 \\
(0.22)\end{array}$ & $\begin{array}{c}2.01 \\
(0.28)\end{array}$ & $3.34 n s$ & $\begin{array}{l}17.11^{* * *} \\
36<42\end{array}$ & $\begin{array}{l}\text { At } 36: 7.28 * \\
2>1 \\
\text { At } 42: 10.61 * * \\
2>1,3 \\
\text { At } 50: 18.11^{* * *} \\
3>1\end{array}$ \\
\hline
\end{tabular}


Table 4.

Identity statuses in three female groups of personal styles at ages 36, 42, and 50. A comparison conducted by MPlus hierarchical linear modeling with full-information maximum likelihood estimation.

\begin{tabular}{|c|c|c|c|c|c|c|c|c|c|c|c|c|}
\hline \multirow[b]{2}{*}{ Identity status } & \multicolumn{3}{|c|}{ 1. Individuated } & \multicolumn{3}{|c|}{ 2. Traditionals } & \multicolumn{3}{|c|}{ 3. Brittle } & \multirow[b]{2}{*}{$\begin{array}{l}\text { Age } x \\
\text { Group }^{(a}\end{array}$} & \multirow[b]{2}{*}{$\begin{array}{c}\text { Age } \\
\text { effect }^{(\mathrm{a}} \\
(\mathrm{F})\end{array}$} & \multirow[b]{2}{*}{$\begin{array}{l}\text { Group } \\
\text { effect }^{(a} \\
(F)\end{array}$} \\
\hline & $\begin{array}{c}M \\
\text { (S.E.) } \\
\text { Age } \\
36\end{array}$ & $\begin{array}{c}M \\
\text { (S.E.) } \\
\text { Age } \\
42\end{array}$ & $\begin{array}{c}M \\
\text { (S.E.) } \\
\text { Age } \\
50\end{array}$ & $\begin{array}{c}M \\
\text { (S.E.) } \\
\text { Age } \\
36\end{array}$ & $\begin{array}{c}M \\
\text { (S.E.) } \\
\text { Age } \\
42\end{array}$ & $\begin{array}{c}M \\
\text { (S.E.) } \\
\text { Age } \\
50\end{array}$ & $\begin{array}{c}M \\
(\mathrm{~S} . \mathrm{E} .) \\
\text { Age } \\
36\end{array}$ & $\begin{array}{c}M \\
\text { (S.E.) } \\
\text { Age } \\
42\end{array}$ & $\begin{array}{c}M \\
\text { (S.E.) } \\
\text { Age } \\
50\end{array}$ & & & \\
\hline Achievement & $\begin{array}{c}2.19 \\
(0.17)\end{array}$ & $\begin{array}{c}2.86 \\
(0.19)\end{array}$ & $\begin{array}{c}2.54 \\
(0.21)\end{array}$ & $\begin{array}{c}1.28 \\
(0.21)\end{array}$ & $\begin{array}{c}2.20 \\
(0.23)\end{array}$ & $\begin{array}{c}2.10 \\
(0.21)\end{array}$ & $\begin{array}{c}1.35 \\
(0.21)\end{array}$ & $\begin{array}{c}1.70 \\
(0.28)\end{array}$ & $\begin{array}{c}1.70 \\
(0.37)\end{array}$ & $3.55 n s$. & $\begin{array}{l}36.50 * * * \\
36<42\end{array}$ & $\begin{array}{l}\text { At 36: } 15.16^{* * * *} \\
1>2,3 \\
\text { At } 42: 12.68^{* * *} \\
1>2,3 \\
\text { At 50: } 4.56 n s .\end{array}$ \\
\hline Moratorium & $\begin{array}{c}0.40 \\
(0.10)\end{array}$ & $\begin{array}{c}0.10 \\
(0.04)\end{array}$ & $\begin{array}{c}0.43 \\
(0.10)\end{array}$ & $\begin{array}{c}0.22 \\
(0.09)\end{array}$ & $\begin{array}{c}0.03 \\
(0.03)\end{array}$ & $\begin{array}{c}0.19 \\
(0.07)\end{array}$ & $\begin{array}{c}0.43 \\
(0.15)\end{array}$ & $\begin{array}{c}0.16 \\
(0.08)\end{array}$ & $\begin{array}{c}0.25 \\
(0.11)\end{array}$ & $3.12 n s$. & $\begin{array}{l}22.43 * * * \\
36>42<50\end{array}$ & $\begin{array}{l}\text { At 36: } 2.53 n s . \\
\text { At 42: } 3.81 n s . \\
\text { At 50: } 4.24 n s .\end{array}$ \\
\hline Foreclosure & $\begin{array}{l}1.76 \\
(0.14)\end{array}$ & $\begin{array}{c}1.21 \\
(0.16)\end{array}$ & $\begin{array}{c}1.43 \\
(0.20)\end{array}$ & $\begin{array}{c}2.40 \\
(0.21)\end{array}$ & $\begin{array}{c}1.54 \\
(0.19)\end{array}$ & $\begin{array}{c}1.93 \\
(0.18)\end{array}$ & $\begin{array}{c}2.16 \\
(0.23)\end{array}$ & $\begin{array}{l}1.56 \\
(0.24)\end{array}$ & $\begin{array}{c}1.41 \\
(0.31)\end{array}$ & $0.58 n s$. & $\begin{array}{l}37.79 * * * \\
42>50\end{array}$ & $\begin{array}{l}\text { At } 36: 7.37 * \\
2>1 \\
\text { At 42: } 3.97 n s . \\
\text { At 50: } 4.25 n s .\end{array}$ \\
\hline Diffusion & $\begin{array}{c}0.64 \\
(0.11)\end{array}$ & $\begin{array}{c}0.95 \\
(0.14)\end{array}$ & $\begin{array}{c}0.63 \\
(0.12)\end{array}$ & $\begin{array}{c}1.13 \\
(0.14)\end{array}$ & $\begin{array}{c}1.27 \\
(0.18)\end{array}$ & $\begin{array}{c}0.77 \\
(0.13)\end{array}$ & $\begin{array}{c}1.11 \\
(0.21)\end{array}$ & $\begin{array}{c}1.53 \\
(0.23)\end{array}$ & $\begin{array}{c}1.06 \\
(0.19)\end{array}$ & $3.34 n s$. & $\begin{array}{l}13.05 * * \\
36<42>50\end{array}$ & $\begin{array}{l}\text { At } 36: 8.21^{*} \\
2,3>1 \\
\text { At } 42: 5.39 \dagger \\
3>1 \\
\text { At } 50: 3.58 n s .\end{array}$ \\
\hline
\end{tabular}

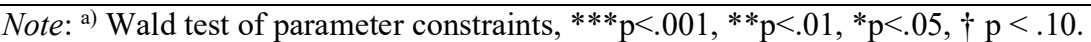



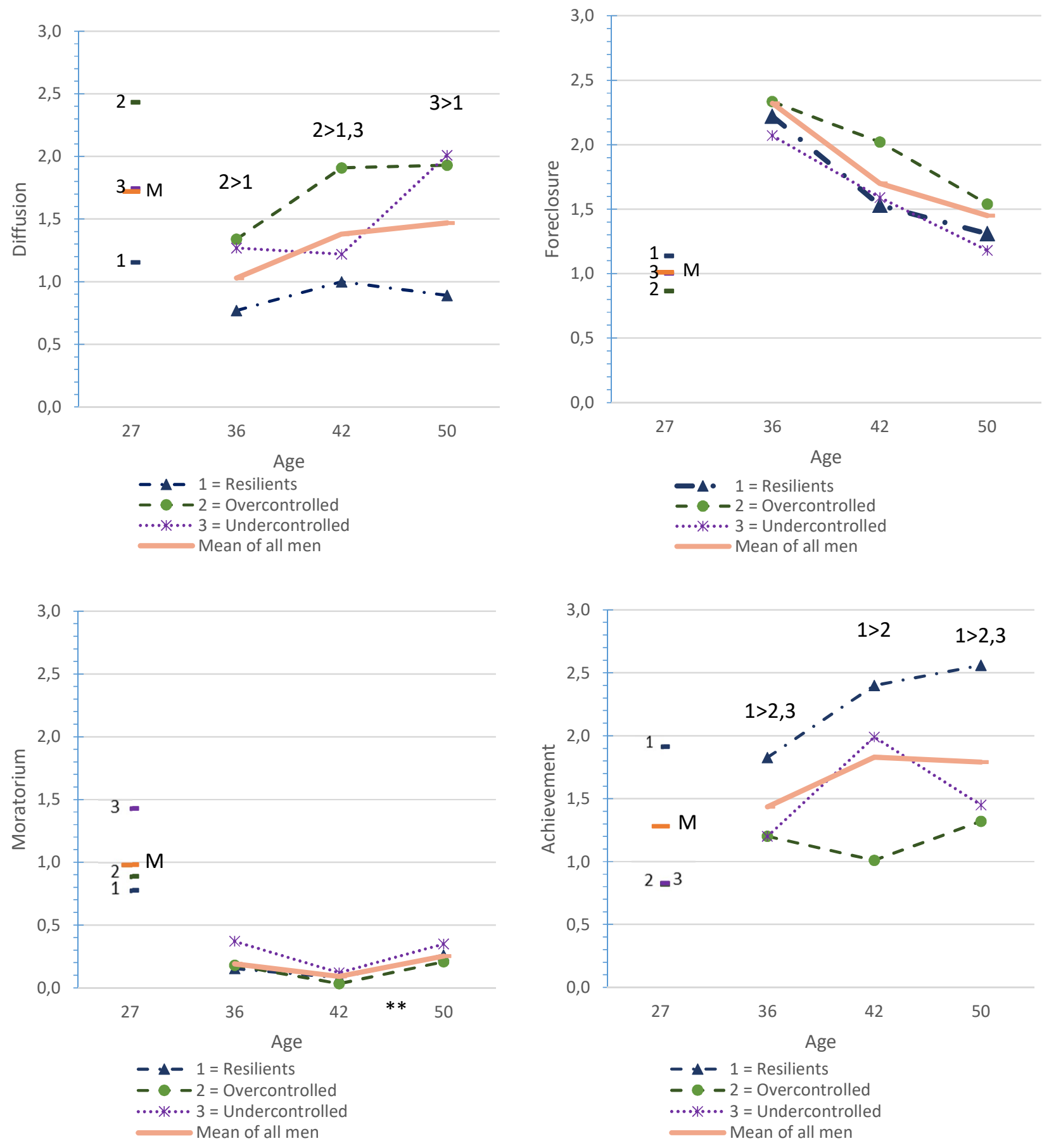

Figure 1.

Age changes of the identity status scores in male personal style clusters across ages 36, 42 and 50, and the baseline for each cluster at age 27. 

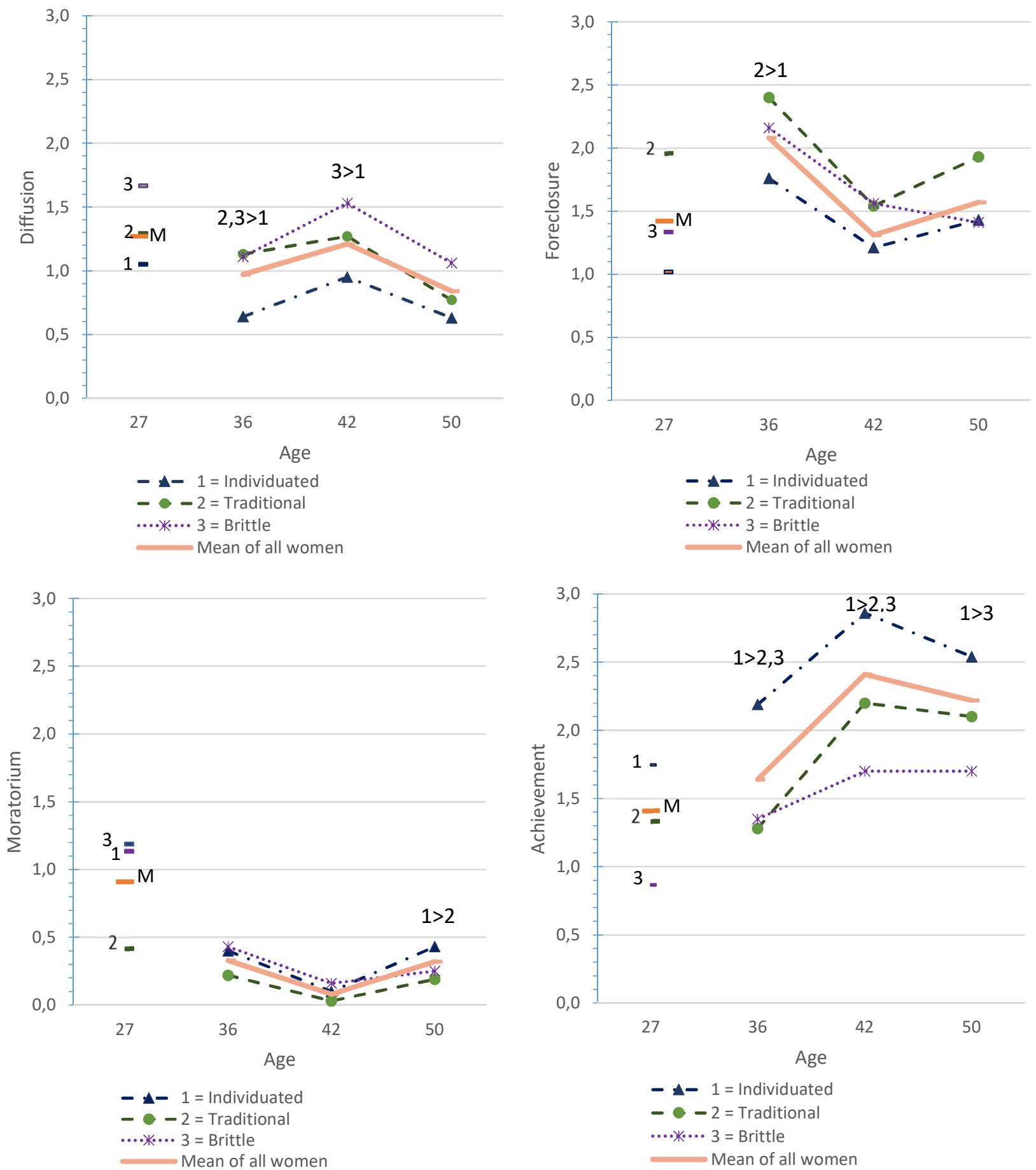

- $\mathbf{\Delta -} 1$ = Individuated

-2 = Traditional

$\cdots * \cdots 3=$ Brittle

Mean of all women

Figure 2.

Age changes of the identity status scores in female personal style clusters across ages 36, 42 and 50, and the baseline for each cluster at age 27. 